\title{
THE FARM ECONOMIES OF THE PLAINS
}

\author{
Michael T. Belongia and R. Alton Gilbert*
}

\section{Introduction}

Our intentions in this paper are two-fold. First, to provide a benchmark for the severity of the debt and income problems, we offer comparisons of recent changes in economic indicators for a ten-state farmbelt region relative to those in the rest of the country. Thus, the first section provides some measurement of the speed and magnitude of changes in these farm sector indicators. Our second objective is to offer empirical evidence on the frequently-heard assertion that the farm economy has been hostage to macroeconomic adjustments. The latter issue is particularly important for policy decisions since, under this view, traditional commodity programs are costly but impotent efforts to increase farm income and relieve farm financial stress. An alternative hypothesis is that farm sector income, because of the low elasticity of demand for farm products, is largely independent of aggregate business cycle fluctuations and that farm problems have their roots elsewhere.

\section{The Scope of the Farm Income and Debt Problem}

Our mandate is to review the farm economy of the plains states. We have taken the liberty of defining this region more broadly to include ten states with large agricultural sectors: Illinois, Indiana, Iowa, Kansas, Minnesota, Missouri, Nebraska, North Dakota, South Dakota and Wisconsin.

Charts 1 and 2 review the patterns of farm income in the ten-state region relative to the remaining 40 states. In Chart 1, farm income in the two areas follows the same general pattern. The only recognizable difference, as expected via the law of large numbers, is greater variation in the ten-state income series. Chart 2 reveals, also as expected, that the share of United States total farm income represented by the ten-state region depends heavily on the fortunes of grain production and prices. Income in these states rose, relative to the other 40 states, during the 1972 73 episode of production cutbacks, unexpectedly large export sales and sharply higher grain prices. During the

*Research Officer and Assistant Vice President, Federal Reserve Bank of St. Louis. The views expressed in this paper are those of the authors and do not necessarily reflect the views of the Federal Reserve Bank of St. Louis or the Federal Reserve System. drought of 1980 and the drought and PIK year of 1983, the share of total farm income produced by these states fell by about five and 15 percentage points, respectively.

Reflecting the above movements in farm income are changes in land values. Chart 3 depicts the USDA survey of national average land value and land values for Minnesota and Kansas, which exhibited the highest and lowest average rates of change in the 1970s of states in our tenstate region. To make comparisons easier, all series are indexed to a value of 100 in 1973 . As the chart shows, land values nationally increased by 200 percent between 1973 and 1981. Over the same period, Minnesota land values increased over 350 percent while average values in Kansas rose less than 150 percent. Since the 1981 peak, Minnesota land values have declined about 40 percent while values in Kansas have declined about 20 percent. To the extent that farmers borrowed on the basis of asset appreciation rather than the ability of those assets to generate income, this range of data suggests that the degree of financial stress is likely to vary widely, even within the farmbelt region.

Charts 4 through 6 compare the status of farm debt at commercial banks for states in this region relative to the remaining 40 states. In Chart 4 , the percentage of farm production loans past due more than 30 days has been lower in the ten-state region than in the remaining 40 states. These data, which have been available only since 1982 , suggest that banks in the farmbelt region also would exhibit lower rates of loan losses, because eventual losses typically are revealed first as delinquencies. Chart 5, however, contradicts this inference by showing sharply higher losses at agricultural banks in the region relative both to agricultural banks in the rest of the United States and all nonagricultural banks. Admittedly, the loan loss data includes all loans, whereas the delinquency data apply only to farm production loans. It is in this latter area, however, where commercial banks are most competitive with other institutions in lending to farmers. Nonetheless, the rising delinquencies and losses are reflected in Chart 6 by returns on equity in the farmbelt region, which have fallen from nearly 15 percent to less than five percent in only five years. Perhaps more striking is the point that the severity of the farm financial problem has caused the return on equity at agricultural banks to fall below that of nonagricultural banks; this reverses the long historical pattern of consistently higher returns at commercial banks significantly engaged in farm banking. 


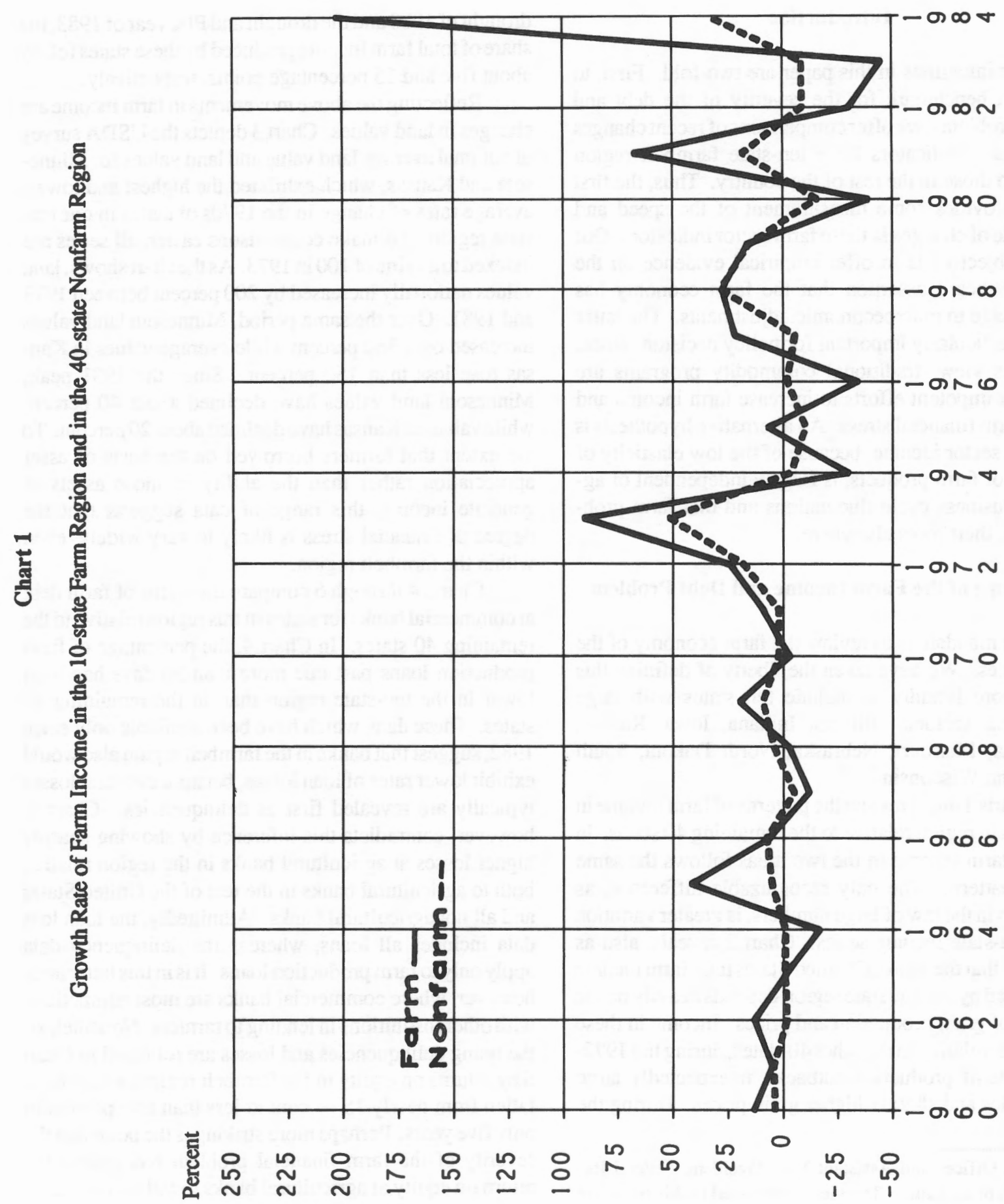




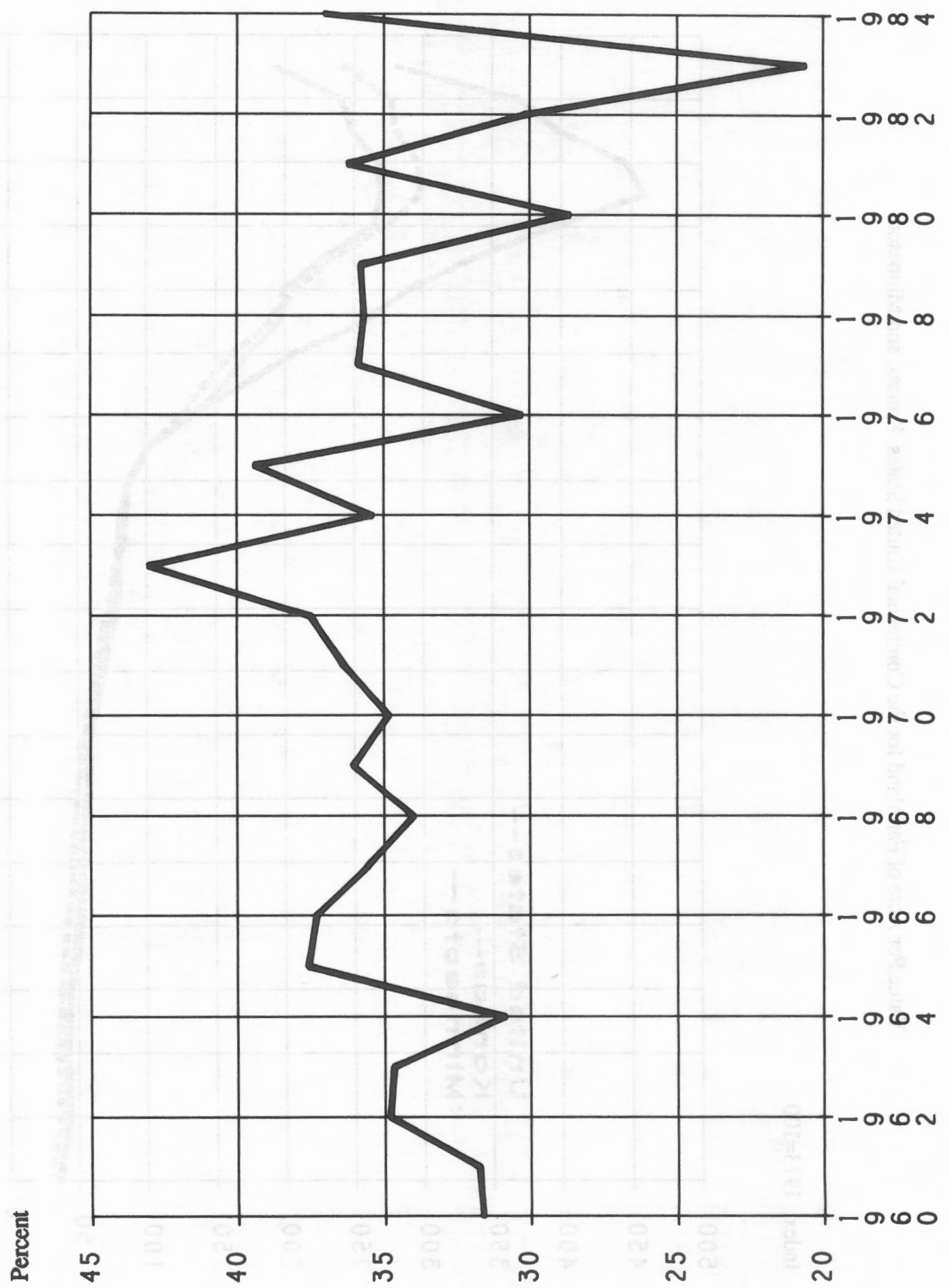




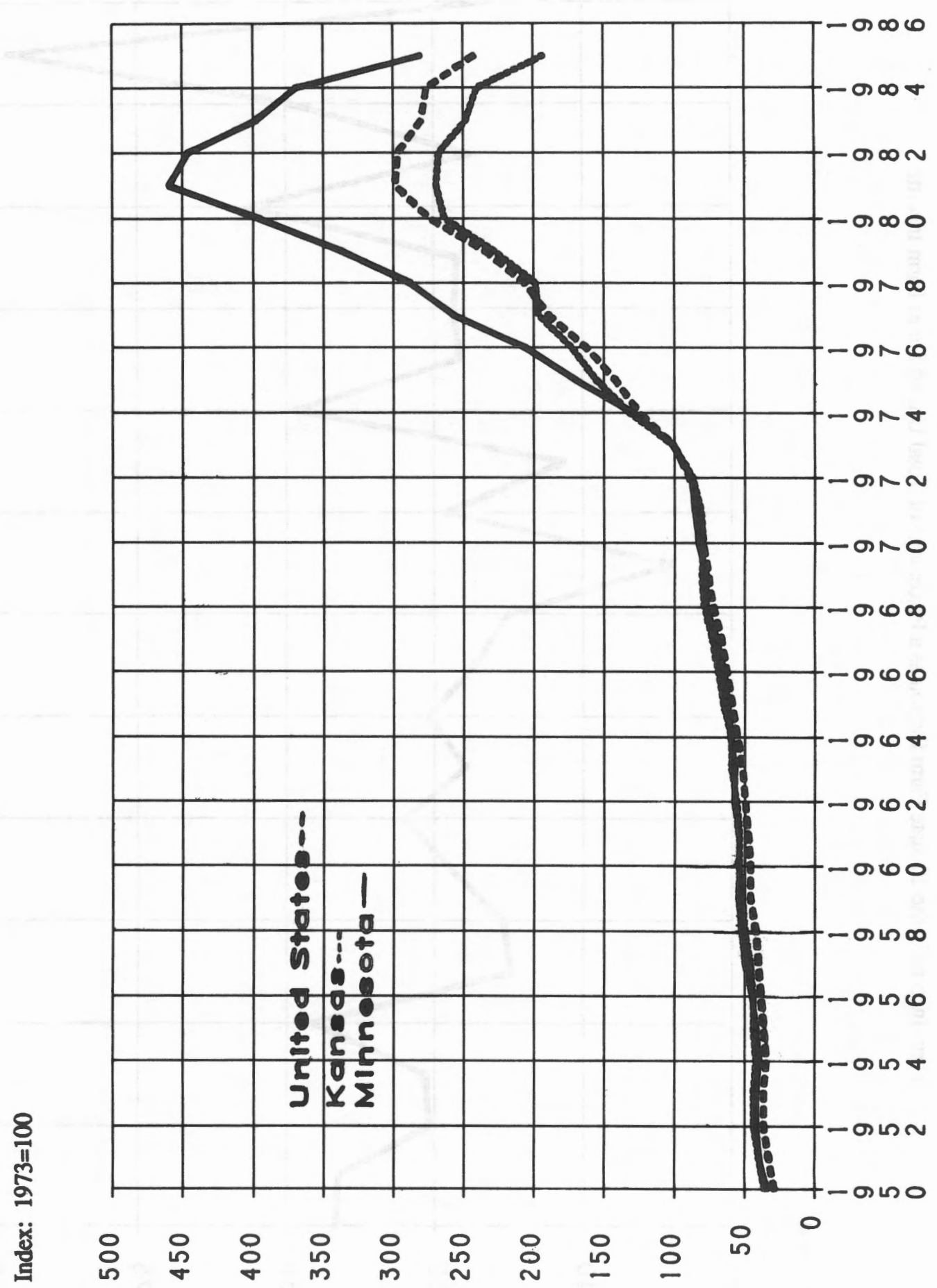




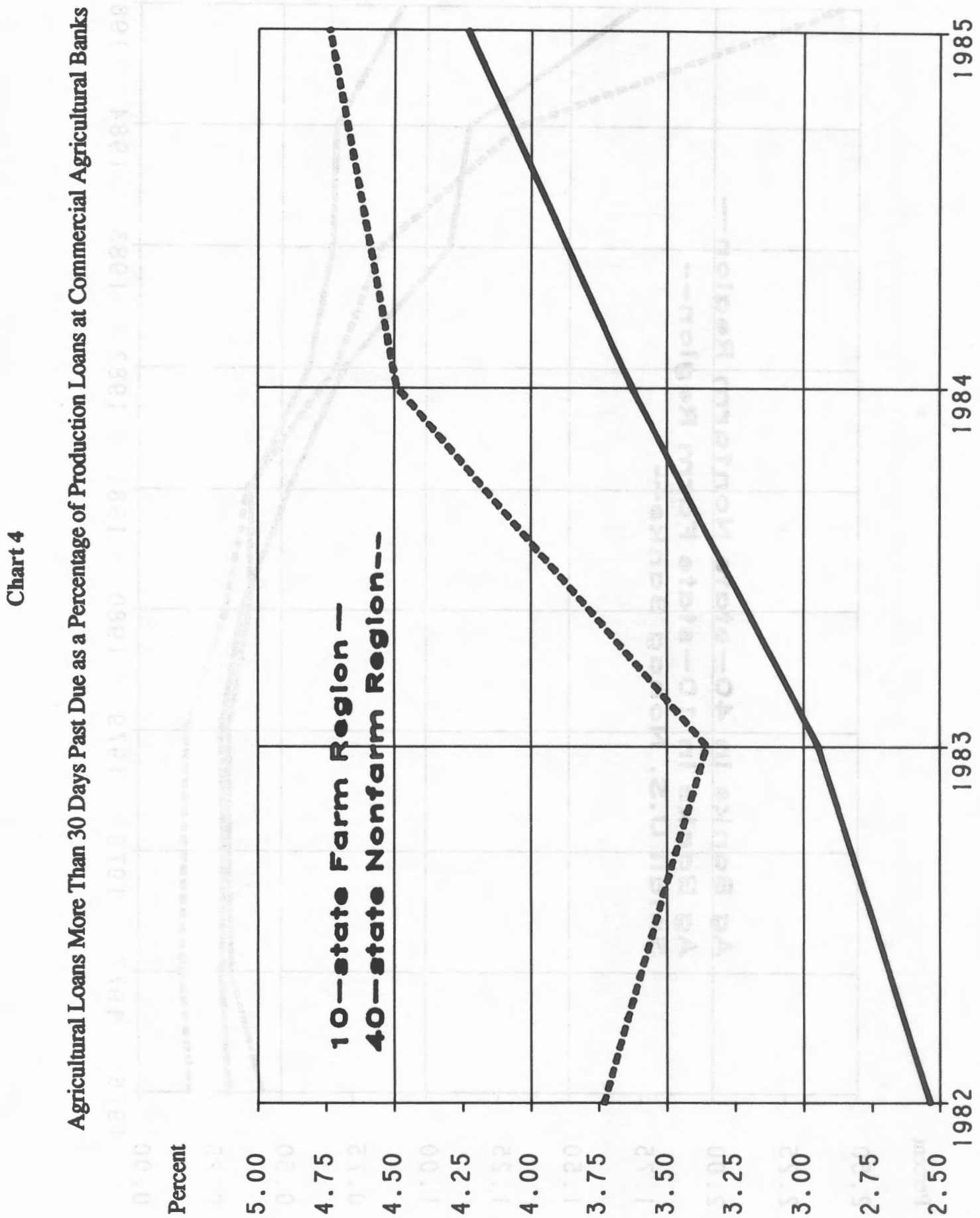



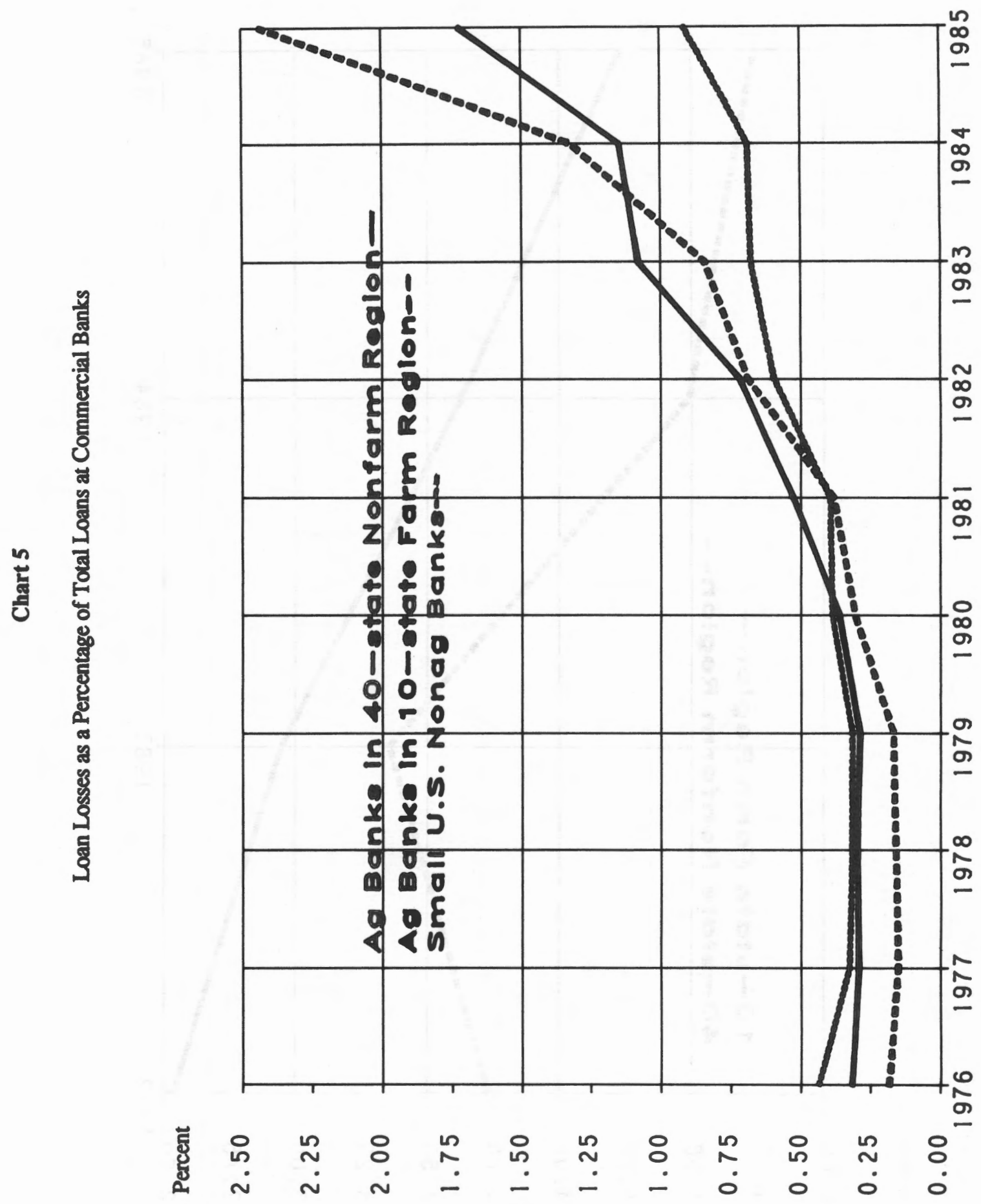


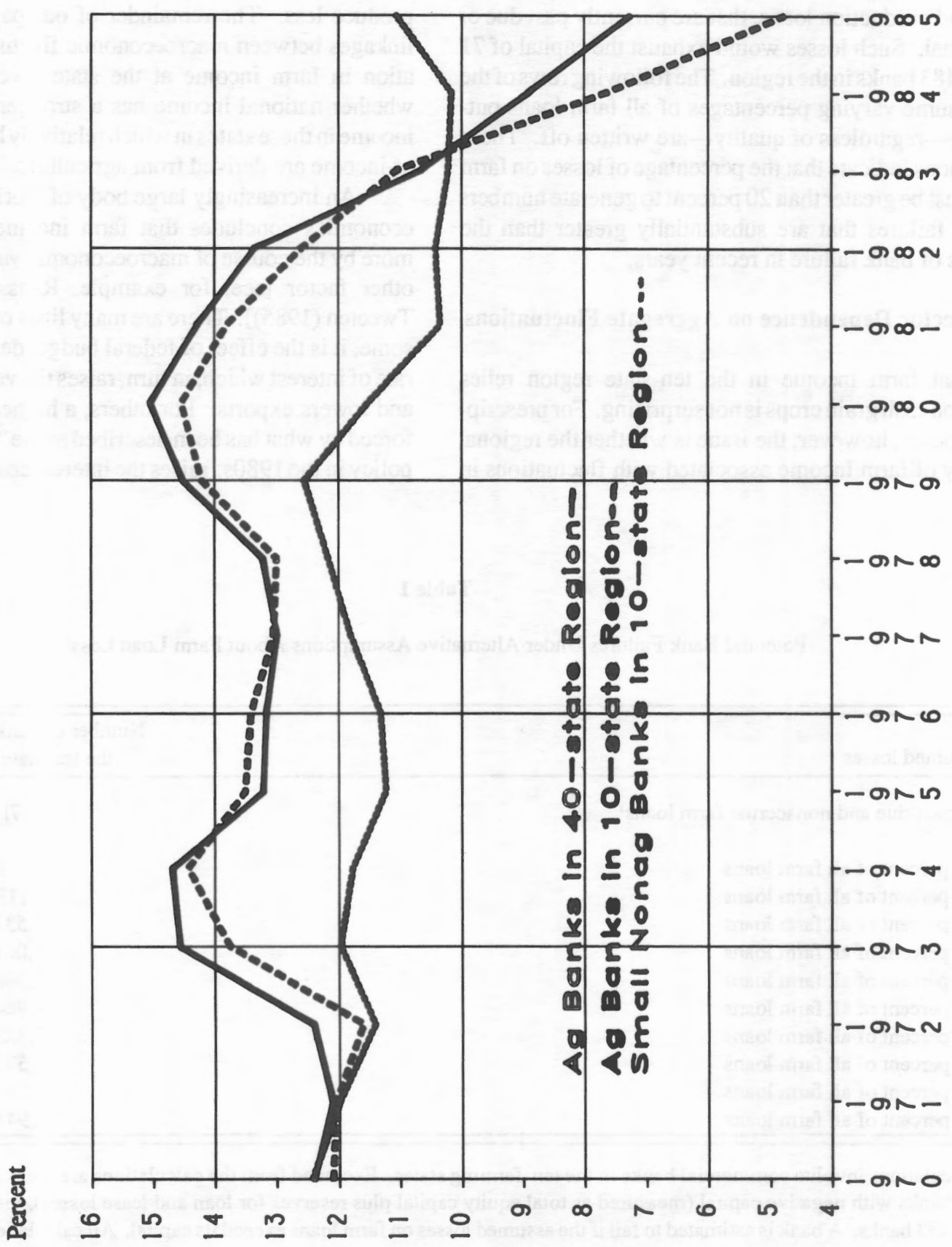


Another means of assessing the potential magnitude of future financial stress in the ten-state region is shown in Table 1. Here, data for the second quarter of 1986 are used to evaluate the possible numbers of commercial bank failures under certain assumptions about farm loan losses. The first line of the table indicates the number of bank failures resulting from losses on all farm loans, both real estate and production loans, that are currently past due or nonaccrual. Such losses would exhaust the capital of 71 of the 5,483 banks in the region. The following rows of the table assume varying percentages of all farm loans outstanding - regardless of quality - are written off. These calculations indicate that the percentage of losses on farm loans must be greater than 20 percent to generate numbers of bank failures that are substantially greater than the numbers of bank failure in recent years.

\section{Farm Sector Dependence on Aggregate Fluctuations}

That farm income in the ten-state region relies heavily on cash grain crops is not surprising. For prescriptive purposes, however, the issue is whether the regional volatility of farm income associated with fluctuations in grain markets (and its impact on the fortunes commercial banks involved in farm lending) is best treated by changes in commodity programs or macroeconomic policies. Or perhaps the issue is best stated as what causes these fluctuations in grain markets and farm income. The mechanics of farm programs are well-known, including their contradictory signals both to produce more and to produce less. The remainder of our paper investigates linkages between macroeconomic fluctuations and variation in farm income at the state level, to determine whether national income has a stronger effect on state income in those states in which relatively high proportions of income are derived from agriculture.

An increasingly large body of work in agricultural economics concludes that farm income is determined more by the course of macroeconomic variables than any other factor [see, for example, Rausser (1985), and Tweeten (1985)]. There are many lines of argument. For some, it is the effect of federal budget deficits on the real rate of interest which, in turn, raises the value of the dollar and lowers exports. For others, a higher real rate, reinforced by what has been described as the "tight" monetary policy in the 1980s, raises the interest cost of farming and

Table 1

Potential Bank Failures Under Altemative Assumptions About Farm Loan Loss ${ }^{1}$

Assumed losses

All past-due and nonaccrual farm loans ${ }^{2}$

10 percent of all farm loans

20 percent of all farm loans

30 percent of all farm loans

40 percent of all farm loans

50 percent of all farm loans

60 percent of all farm loans

70 percent of all farm loans

80 percent of all farm loans

90 percent of all farm loans

100 percent of all farm loans
Number of bank failures in the ten-state region

${ }^{1}$ Calculations involve commercial banks in the ten farming states. Excluded from the calculations are the nonbank banks and banks with negative capital (measured as total equity capital plus reserves for loan and lease losses), yielding a total of 5,483 banks. A bank is estimated to fail if the assumed losses on farm loans exceed its capital. All calculations are based on Report of Condition data for June 30, 1986.

2Instructions for the Report of Condition call for banks to report their past-due and nonaccrual farm loans only if their farm loans exceed five percent of their total loans. For this reason, the number of bank failures under this assumption may be biased downward, since there may be several banks with less than five percent of their loans to farmers that aiso have relatively low capital ratios. 
reduces asset values. Finally, others [e.g., Tweeten (1983), Starleaf, Myers and Womack (1985) and Chambers (1984)] find that unexpected changes in money growth have long-run effects on the relative prices of farm products. Whatever the specific line of reasoning, however, the nature of the argument is that the relatively inelastic short-run agricultural supply functions and the auction characteristics of markets for farm products, which facilitates quick adjustment of their prices to aggregate shocks, make farm income more volatile than the income of "fix-price" sectors.

One way to test this conjecture concerning the effects of changes in national income on farm income is to estimate a system of equations of the following form:

$$
\text { YFARM }_{i k}=\alpha+\beta \dot{Y}_{t}+e_{i} i=1-50
$$

where

$$
\begin{array}{ll}
\text { YFARM }_{i t}= & \text { the growth rate of farm income in state } \\
& \quad i \text { in year } t ; \text { and } \\
\dot{Y}_{t} & =\text { growth rate of GNP in year } t .
\end{array}
$$

Since deflating both sides of the equation would have no effect on the results, all values are in nominal terms.

This variant of the Lucas model [Lucas (1975)] would suggest that a state's farm income would depend on the trend or "natural" rate of aggregate income growth $(\alpha)$ and cyclical movements in GNP $\left(B_{i}\right)$. To test the model in its most general form, the implication would be that farm income at the state level has a significant trend $\left(\alpha_{1} \neq 0\right)$ and is related significantly to cyclical variations in GNP $\left(B_{i} \neq 0\right)$. This hypothesis is tested by estimating a set of 50 equations, as expressed in (1), with annual data for 1959-84. Although the common right-hand-side variable in all equations reduces the estimation to OLS, the system was estimated as a set of seemingly unrelated regressions to facilitate testing of hypotheses across equations.

A second approach to testing the effects of macroeconomic fluctuations on farm income involves the estimation of equations similar to equation (1) above, except with state personal income substituted for state farm income as the dependent variable. If farm income is more sensitive to macroeconomic fluctuations than the income derived from other sectors of the economy, because of the relatively inelastic short-run agricultural supply functions and the auction characteristics of markets for farm products, personal income would tend to be more responsive to fluctuations in national GNP growth in the states with relatively large farm sectors. The next section reports a test of the hypothesis that the coefficient on GNP growth in regression equations with state personal income as the dependent variable is larger in the ten-state region of farm states than in the other 40 states.

\section{Results}

\section{Dependent Variable: State Farm Income}

The results for individual equations (not reported) indicate that six states had significantly negative intercept terms. The implication of the model is that the growth in farm income in these states-Alabama, Arkansas, California, Oregon, Texas and Wisconsin-is following a significantly negative trend. Twelve states-Arkansas, California, Florida, Massachusetts, Missouri, New Hampshire, New York, Oregon, Tennessee, Texas, Utah and Wisconsin-exhibit a significantly positive cyclical relationship between the growth in state farm income and GNP.

Several things are interesting about these results, aside from the relatively small number of states for which a significant trend or cyclical path is found. First, of the ten states included in our definition of the farmbelt, only Wisconsin had a significant trend coefficient; only Missouri and Wisconsin from this region had significant cyclical patterns. That is, of the ten states typically identified as a concentrated farming region and under farm-related financial stress, at least eight reveal no significant connection of farm income to fluctuations in GNP. This evidence would appear to rebut the assertion that macroeconomic linkages have been the primary source of farm sector problems.

Second, the states in which farm income and GNP are related may be separated loosely into two groups: states with relatively small farm sectors and states whose agriculture is composed largely of commodities with elasticities of demand higher than those for traditional crop items. In the former category, one might think of Massachusetts, Oregon, Tennessee and Utah. In the latter category, the Florida citrus industry, the livestock industries of Missouri and Texas and the dairy industries of New York and Wisconsin may be the cause of their cyclical responsiveness to GNP. While this ad hoc dichotomy should not be pushed too hard, the results (the virtual lack of relationship between state farm income in the tenstate region and GNP) do not support the alleged dominant influence of macroeconomic disturbances on farm income.

\section{Dependent Variable: State Personal Income}

Tests of the model's implications for farm policy prescriptions investigate whether personal income growth follows a trend and cyclical pattern that is common 
Table 2

Trend and Cyclical Behavior of Personal Income in Farm and Nonfarm Regions

$$
\begin{aligned}
& \text { (1) } \Delta \ln Y 1 Q_{l}=-0.484+0.991 * \Delta \ln Y_{t} \\
& \text { (0.49) (8.53) } \\
& \overline{\mathrm{R}}^{2}=0.74 \quad \mathrm{DW}=2.31 \\
& \text { TEST }_{\alpha 10}={ }_{\alpha 40}: F_{1,24}=5.68 \text { (significant } a 0.05 \text { level) } \\
& \beta_{10}=\beta_{40}: F_{1,24}=2.73 \\
& \text { (2) } \Delta \ln Y 49=1.861+0.799 * \Delta \ln Y_{t} \\
& \text { (233) (8.40) } \\
& \overline{\mathbf{R}}^{2}=0.74 \quad \mathrm{DW}=1.25
\end{aligned}
$$

Absolute values of t-statistics in parentheses.

across all states; that is, $\alpha_{1}=\alpha_{2} \ldots \alpha_{50}$ and $B_{1}=B_{2}=\ldots$ .$=B_{s 0^{\circ}}$. This test involves comparing the SSE for the system of 50 equations estimated subject to these restrictions with the SSE for the unrestricted estimation. The difference (415.7), distributed as a $\chi^{2}$ with 98 degrees of freedom, is significant at the traditional 0.05 level. The implication is that the response of personal income growth at the state level to the growth in GNP varies across states. It is not clear, however, whether the relative sizes of the farm sectors or other dominant industries (e.g., manufacturing) are responsible for this result.

To investigate this relationship further, the noise introduced by individual state data was reduced by creating data series of personal income for our two regions:

$Y 10=\sum_{j=1}^{10} Y_{i}$ and $Y 40=\sum_{j=1}^{40} Y_{j}, i \neq j$. Two equations of the form in (1) then were estimated over the same set of annual data. The results are shown in Table 2.

Here, the results are somewhat more interesting in that, for the regions as a whole, growth in personal income in the "nonfarm" region has significantly positive trend, whereas the trend growth rate in the farm region is not different from zero. The point estimate of the slope coefficient is larger in the ten-state regression, but not significantly larger than that for the 40-state regression. Overall, the results generally support the observation that agriculture is a declining industry. The failure to find different cyclical responses across farm and nonfarm regions, however, casts doubt on the notion that aggregate fluctuations are an important source of disruptions to the farm sector.

\section{Conclusions}

A description of changes in farm income and indicators of farm bank performance in farm belt states show clearly that financial conditions have deteriorated sharply since 1981. Particularly noteworthy is the observation that the returns on equity at agricultural banks have been lower than the returns earned by nonfarm banks in recent years. The sharp downward adjustment in farm asset values and low farm income since 1981 are no doubt responsible for this reversal in the long history of superior returns at agricultural banks.

Our empirical investigation is addressed to the frequent assertion that macroeconomic fluctuations are the primary source of farm sector problems. We examine the influence of growth in national GNP on state farm income and state personal income. GNP growth has little effect on farm income and appears to affect personal income equally, regardless of the size of a state's farm sector. Personal income growth in farm states does not have a significant trend, whereas nonfarm states have a significantly positive trend in personal income. This latter point is consistent with the view that the farm sectors of farmbelt states are declining industries, which tend to depress income growth in farm states. 


\section{REFERENCES}

Chambers, Robert G. "Agricultural and Financial Market Interdependence in the Short Run." American Journal of Agricultural Economics. 66 (1984). 12-24.

Lucas, Robert E. "An Equilibrium Model of the Business Cycle." Journal of Political Economy. 83 (1975). 113-45.

Rausser, Gordon. "Macroeconomics and U. S. Agricultural Policy." U. S. Agricultural Policy: The 1985 Farm Legislation. In Bruce L. Gardner (ed.). Washington, D.C.: American Enterprise Institute.
Starleaf, Denis, William H. Meyers, and Abner Womack "The Impact of Inflation in the Real Income of U. S. Farmers." American Journal of Agricultural Economics. 67 (1985). 384-89.

Tweeten, Luther. "Impacts of Federal Fiscal-Monetary Policy on Farm Structure." Southern Journal of Agricultural Economics. 15 (1983). 61-68.

"Farm Financial Stress, Structure of Agriculture and Public Policy." U.S. Agricultural Policy: The 1985

Farm Legislation. In Bruce L. Garner (ed.). Washington, D.C. American Enterprise Institute. 